\title{
STUDIES ON CALORIC TEST FOR THE PURPOSE OF THE DIAGNOSIS OF VESTIBULAR LESIONS
}

\author{
By \\ K. OKAMOTO
From the Department of Otorhinolaryngology, School of Medicine, Keio University
(Director: Prof. T. Nishihata)
From the 2nd Tokyo National Hospital.
(Director: Dr. H. Ino)

Clinical studies on vestibular function test, particularly on caloric test were described.

A brief review was given of the results of these examinations in normal subjects.

$Z$-test, a new method of caloric test, devised by Ino, and caloric pattern test developed from the $Z$-test (Ino, Okamoto) were described.

Observations on a servies of 30 cases of Ménière's disease as peripheral vestibular disorders and of 32 cases of central vestibular disorders including brain tumor were presented.

Results Obtained from the exsminations of spontaneous nystagmus and positional nystagmus, with observations by rotation test, alternated hot or cold test, Z-test and Caloric pattern test were as follows.

1. Spontaneous nystagmus gave no diagnostic indication.

2. Positional nystagmus: In about 50\% of cases of Ménière's disease direction fixed positional nystagmus were presented, and this is considered desirable to put into practice as a routine test of vestibular function.

3. Ashibumi-test: In many cases of Ménière's disease, the deviating side was commonly directed to the slow phase of nystagmus.

4. Rotation test: Vestibular asymmetry was observed infrequently in this method. For this reason, this test is considered to give no indication of the localization of lesions.

5. Alternated hot or cold test: The findings of directional preponderance (D.P.) and canal paresis (C.P.) presented no indication of whether lesions were located in central or peripheral.

6. Z-test: Investigation of the latent period seemed to direct to the localization of lesions.

7. Caloric pattern test: Type 2 examined by this method showed the characteristic features of peripheral vestibular disorders, and it might be thought as a vestibular recruitment phenomenon. In many cases of central vestibular disorders were often found Type 3, or Type 4. This suggested that they are regarded as an expression of central checking mechanism.

In Ménière's disease, Type 1 or Type 2 were frequently found. Type 1 usually showed D.P.,

and C.P. was oftentimes found in Type 2.

This suggests that C.P. is regarded as a sign of cupular affection and D.P. is regarded as. that of utricular disorders. 


\title{
病巣の局在診断を目的とした温度性眼振 検查方法に関する研究
}

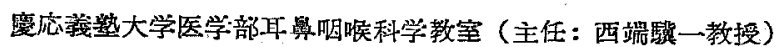

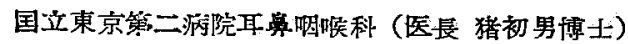

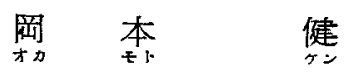

目次

I緒言

1検查方法

1. 自発眼振

2. 頭位眼振

3. 足踏検查

4. 迴檕検查

5. 溫度検查

a) 冷湓交互試鍳

b) Z-test

c) Caloric Pattern Test

III検查対象

$N$ 検查成續並びに洘按

1. 自発腿振

2. 謴位眼振

3. 足踏検查

4. 迴転梌香

5. 溫廅検查, 冷溫交互試験

6. Z-test

7. Caloric Pattern Test

$V$ 結 論

\section{I. 緒言}

睹最を主訴として外来を訪れる患者は多いが，その臨 床像は多種多様であり，各種の臨床検查を行つてもその 原因的疾患を明らかになし得ない場合が少くないここの 上5な場合，多くはこれを単に瞒最症，あるいはメ二エ 一几氏症候群という名の下に一括して放置しておくのが 現状である。このような盿最症に対して，前庭譏能検查 を行つても，病巣部位を確夷に䛦断することは極めて困 難である・そこで私は病巣の局在診断を目的として，徉 来の前庭譏能唡查法を再検詰するととすに，特に Z-test (猪)，及びこれより新しく発展せしめた Caloric Pattern Test (猪, 岡本) (仮称)なる検查法について検討を 加え，これらを含めた各種温度性眼振検查の病亲局在診 断上の価值について検討を加える 目的で本研究を企て
た。

今日一般臨床に用いられている前庭譏能検査法む，自 発腿振; 頭位眼振の検查, Romberg Test, 指示試験, Goniometer Test, 起立検查, 步行検查, 廘眼書宁検 查, 足踏検査, 廻転検查, 温度検査等である.本来の前 庭機能を検查するとい5立場からすれば，迷路になん等 の刺战を加えることなく，そのま〉現れる自発应状の絶 查に重点をおくべきであろう.そのためには Romberg Test, 指示試験, Goniometer Test, 起立検查, 步行积 查，足踏检查，遮腿書字検查等が望ましい，乙かし実際 の㟝療に当つては，眼球振璗の䄼査が有力な診断の手脚 りとなることが多いこの場合も迷路に何らかの刺战を 加えることなしに現れる自発眼振の椧查を対象としたい、 が，自発眼振は常に現れるとは限らない。自発眼振の認 められない場合は頭位眼振の観察が必要となつてくる。 頭位眼振の観察が，病巣の局在診断上有力な手掛りとな ることは周知の通りである。

自発眼振も頭位眼振も認わられぬ場合は, 実験的に迴 転刺战や，温度刺㦸を迷路に加え眼振を誘発せしめ,こ れを観察する方法がとられる・眼脤を対象とするこれら の検查は，その成績を量的にかなり正確に判定し得る利 点がある・

しかるに今日一般に行われている迴転検查中温度积查 の成績判定は，正常者について得られた正常値と，患者 について得られた值とを比較する方法がとられていた が，正常值が相当広範囲にわたつているため，病的例を 正常值と比較することはかなり困難であつた・これに反 して，同一患者について左右迷路の検查成績を比較する 方法，即ら眼振左右差を検査する方法法多くの利点をる つている・

迴転㭘查は Barany の方法を始めとして，幾多の変 法が登表され今日に至つているが, 最近 van Egmond， Graen, Jongkees (1952) 16) 等は半規管の 生理的刺战 は角加速度で，これにより内リンパの流動が河起され， Cupula が偏位し，これが刺战となつて眼振が笔来する 
とい〉, その角加速度を任意に変化させ，これと眼振と の関係をしらべ所謂 Cupulogram を作成し，この Cupulogram より半規管の與奪性を 判断し得ると述べ ているが，いずれの迴転検查法む左右迷路を同時沉刺战 するといら大きな欠点をるつている・これに反し温度性 眼振険查では，左右迷路を一側つ〉別々儿険查し得ると いう利点を持つているから，臨床検查法としてはより広 く採用されるべきであろら。

われわれは温度性眼振の 基礎的問題を検討すると共 に，铨查法そのものについてる吟味を加えているが，本 論交では泠温交互試験, Z-Test (猪), Caloric Pattern Test（猪，岡本）の三険查法の成綪を中心述べ，他の 㭘查法による成續と比較検討することにした。

なお Caloric Pattern Test の病巣診断上の意義に ついては，家鬼による中枢及び末梢の破買丰験によつて 確認しているので，その䛨細に関しては後日発表の予定 である.

\section{II. 検查方法}

私は眩最症患者の桧查に当り，第 I図 a）b）の如き 㭘查用紙を作製し，これに準じて検查を行つた。

第 1 图 (a)

MEURO-OSOLOGICAI. EARTHATIOH VESTIBULAR TESTS

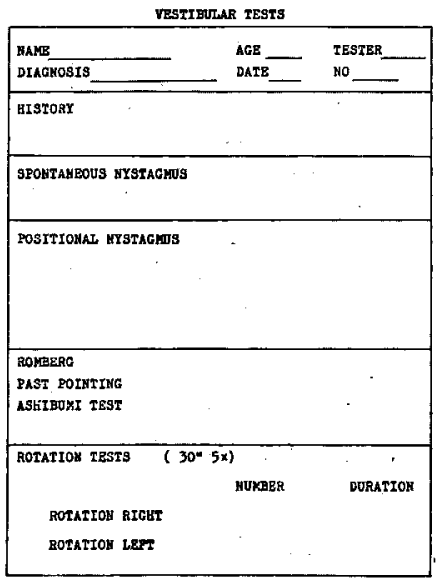

以下簡単に各検查方法について述べる・始めに詳しい 問診を行らことは勿論であり文精密な聴力検查を併せ行 5 .

1. 自発眼振

直立頭位にて直前方，上方，下方，左側方，右側方を みざ検查する方法で周知の通りである。

2. 頭位眼振

仰卧位，左右側卧位，惩吊頭位，腹位につき行い，正
第 1 图 (b)

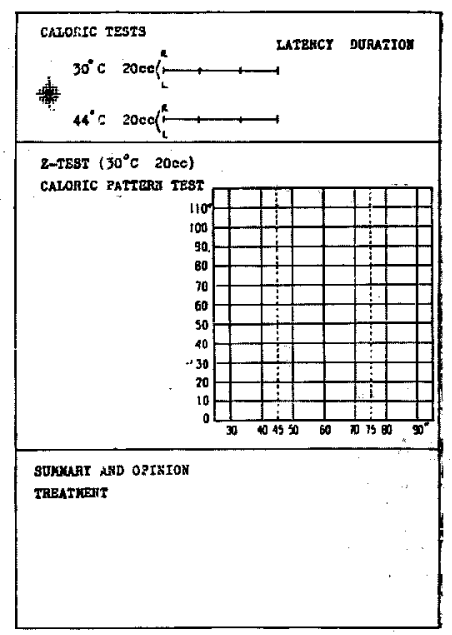

面視で眼振の認められない場合は左右上下を 疑視させ て；その時の眼振の状態を観察し記載する。

\section{3. 足踏榆查}

福田 (1943)17) の提昌世る方法に従い50 歩足踏さ せ, その移行角, 移行距離, 廻転角, 偏倚軦跡等につき 観察した。

4. 迴転検查

従来より種タの方法が行われているが，今日臨床検查 法として一般に行われている方法は，20秒10 迴転の Barany 法及び 30 秒 5 迴転の Kobrak 法である. 最 近は所謂䦣值下迴転装置を使用する検查法が盛んに行わ れるようになつてきた・これらの方法のうち、Bärany 法は刺战が 余りに強く，患者に与える. 副作用も強過ぎ る・閔值下迴鞋置による方法は，装置の点で一般臨床 に用いるには難点がある・そこで私は迴転刺战としては， 30 秒 5 延転法を用い，廻転停止後裸眼にて 眼振側を 視させ，眼振数及び眼振持続時間の則定を行つた。

5. 温度検查

本法にも種々異つた方法があるが，今日をでに発表さ れた主な温度検查方法を一括表示する (第 1 表).

a) 冷温交立試験

温度検查を行うに当つては，迷路に加える刺战はでぎ， るだけ小さく，患者に与える副作用はできるたけけ軽く，， しか子検查成績が正砤であることが望ましい.この点で Barany の大量注水法は不適当で，小量注水法か望亲し い. 㕛単一の冷水あるいは温水刺战では眼䅶の方向優位 性は判断できない.そこで私は Hallpike 等の提㘿す 
第 1 表 主なる溫度検查方法

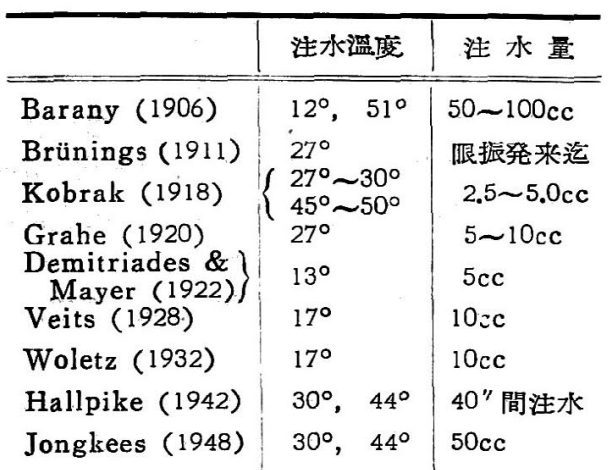

る冷温交互試験を行つた。その注水条件として私は注 水温度，注水量について詳細な検討を行つた猪，早川 （1951） 19）の報告に基づき，冷水として $30^{\circ} \mathrm{C} 20 \mathrm{cc}$, 温 水として $44^{\circ} \mathrm{C} 20 \mathrm{cc}$ を10 秒間で外耳道後上壁飞注水 する方法を用い，眼振の観察にはフレンッェルの眼鏡を 使用している．温度性眼振の検查に当つては眼振の発 来，終結の判定が困難とされているが，本法によれば患 者に与える不快感も少く, 又眼振の開始, 終結の観察も 比較的容易である。

\section{b) Z-Test}

先に㒂 (1955) 20)により提唱されたら検査法で，その 主眼とするところは温度性眼振検查に批りる真の意味の 潜伏時間を測定すると共に眼振持続時間を計測し，両者 の関保より中枢性疾患か，末佾性疾患かを判定する方法 である・即ち從来行われている温度検查にみられる潜伏 時間は，種々の要因によつて变化するもので，Schm. altz (1932) 40) の実験によつても，側頭骨の解剖学的構 造によつてかなり左右されることが分る。そこで猪は温 度検查を再吟味し，真の意味の潜伏時間の測定方法を考 察すると同時に，この潜伏時間と眼振持続時間の関係か ら病巣診断がかなりの範囲で 可能であることを示唆し た・本法の害際を簡単に説明すると，最初坐位で前屈 $30^{\circ}$ の頭位で注水を行う．この頭位では水平半規管が水 平位 (indifferent position) になつているために，温 度刺战が加つても内リンパの流動が生じない.この頭位 で 60 秒間置き，乙かる後に頭位を 2 秒間で直立頭位に 変換する.この頭位変換後眠振発来迄の時間, 即ら真の 意味の潜伏时間之，眼振持続時間を計測する 方法であ る・な和眼振の観察に当つてはフレンッェルの眼鏡を使 用している。

c) Caloric Pattern Test

上述の Z-Test 注頭位をあらかじめ前屈 $30^{\circ}$ Kして
第 2 図 Caloric Pattern Test 裝置

a) indifferent positionにて注水を行う

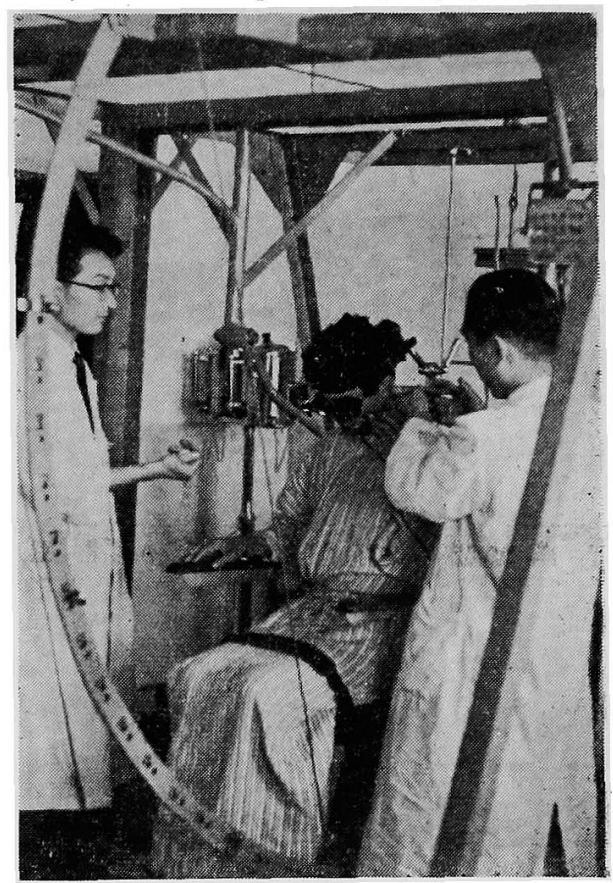

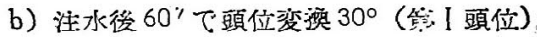

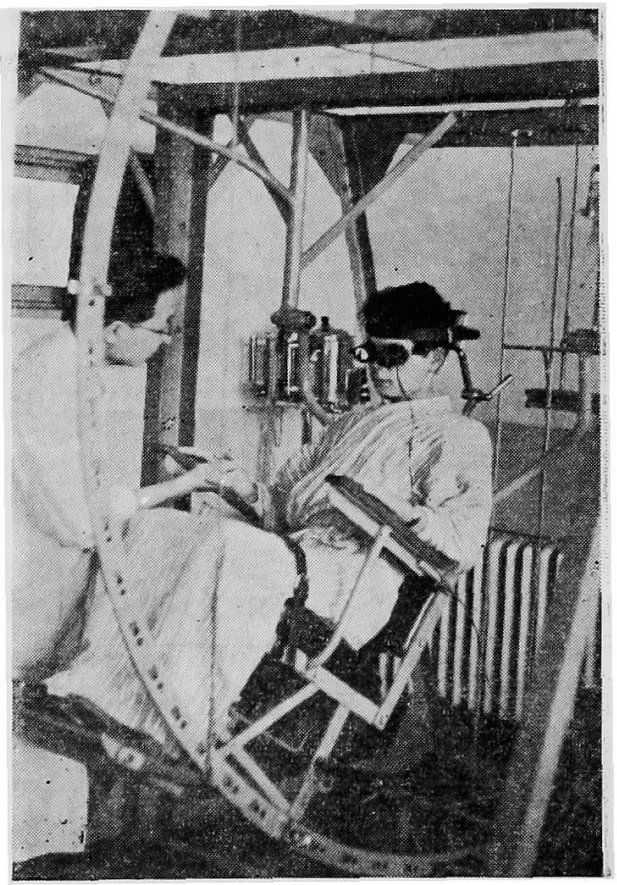


c) 同 $60^{\circ}$ (警】頭位)

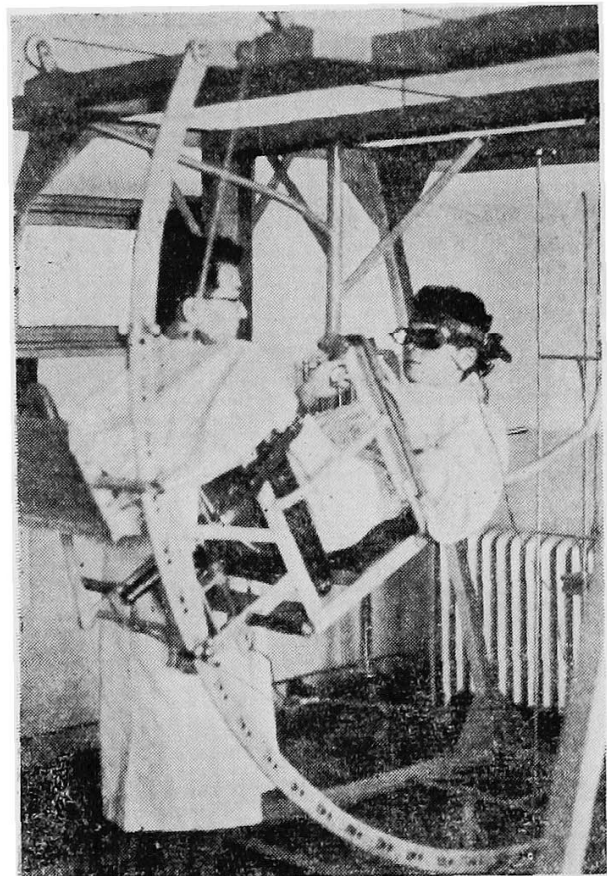

d) 同 $90^{\circ}$ (宣留頭位)

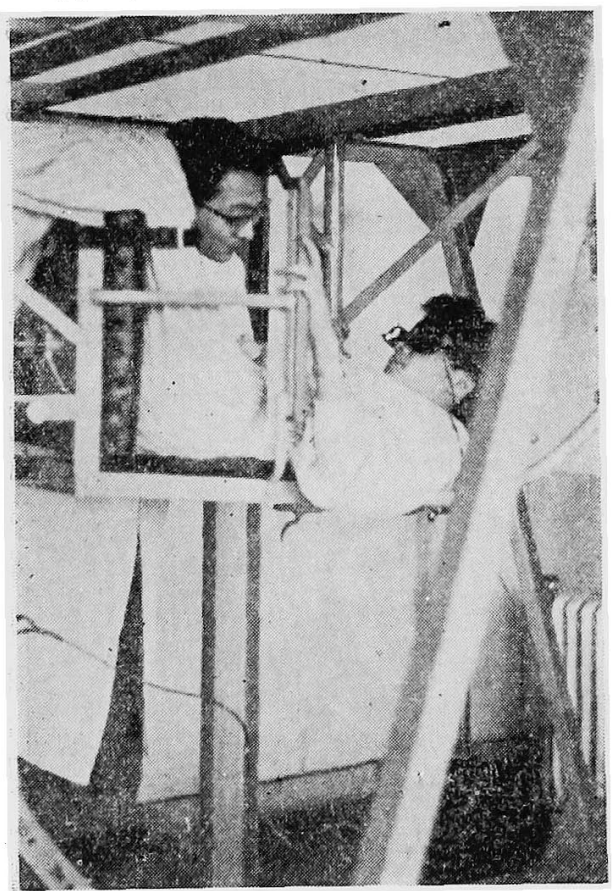

置き，注水後 60 秒後に直立頭位にする 方法であるが， 本法を以つてしては眼振の発来を見ない場合があり，か 〉る場合には Z-Test による判定は不可能となる・そ のため頭位を更に後屈せしめ，内リンパの流動を強め， 末㭶迷路に加わる刺皒を階段的に強め,これにより得ら れる眼振の潜伏時間及び持続時間を湘定すると共に，各 頭位に䋆ける 眼振持続時間を pattern として表わすこ とにした．そのため私は第2 図の如さ装置を作成，使用 している.

即ち両耳を軸として前啳に廷転するブランコ装置で， この迴転は $0^{\circ}$ 〜 $90^{\circ}$ ま $5^{\circ}$ らつ任意の角度まで迴転さ せることができる・即ち患者の両耳を廷転軸と一致せし め, 前屈打よそ $30^{\circ}$ の位置 (indifferent position) に 頭を固定する・この頭位で注水を行い，60 秒後に任意 の角度に廷転させ，その位置に固定し，眼振を観察する ものである.この場合フレンッェルの眼鏡を使用寸るこ とは Z-Test の場合と同様である.私は後屈 $30^{\circ}$ (原頭 位より後屈 $30^{\circ}$, この場合水平半規管の水平面に対する

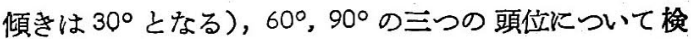
查した. $30^{\circ}$ の頭位は前述せる Z-test の場合と同じで ある・

この $30^{\circ}$ の頭位を第 I 頭位, $60^{\circ}$ の頭位を第】頭位， $90^{\circ}$ の頭位を第四頭位とすると，第向頭位は水平半規管 が垂直の位置になつている頭位であるから，最も眼振が 出易い位置である・内リンバの流れは第】頭位が最も弱 く，第四頭位が最す強いことになる・このように頍位を 変化させて迷路に与える刺㦸を次第に強めていつた場合 の眼振持続咕間が，どのように変化するかを検討するこ とにより，温度性眼振を定量的に検討乙得ると考え，本 法により得られた眼振持続時間を一つの pattern とし て表わすことにした。

注水条件としては， $30^{\circ} \mathrm{C} 20 \mathrm{cc}$ を 10 悡間で注入し， 注水開始後 60 秒で，それぞれの頭位に 2 秒間で変換を 行らこととした.

\section{III. 検 查対 象}

眩最を訴える患者は多く，その原因は種々雑多で，眩 暈を引起す原疾患につを個々に検討を加えることは極め て困難である・そこで私はこれを末梢性疾患と中枢性疾 患とに大きく㘯け，その各々について検討を加えること とした.

こっで云ら末㭘性疾患とは，迷路及び前庭神経に障㧹 を有するものを指し，中枢性疾患とは，前庭神経核及び その上位中枢に障碍を有するすのをいう. 
末梢垁患の代表として私はメ =エール氏病を検查の対 象とした・メニエール氏病の定義と解积は各研究者によ り一定していないが，私は次の如き臨床像を呈するもの をメニエール氏病として取扱つた。即ち眩最発作が乫発 的に起り，この発作は短時間で終り，しかも周期的に発 作を反覆し，間摒期には 発作症状から解放される。難 聴，耳鳴は多くは一側性で，感音性難聴の德力像を示す あの.このような臨床像を呈するるのを私はメニメール 氏病としたが，これは true Mènière's'disease (Wodak 1953) ${ }^{46)}$, typical Ménière's disease (Mygind

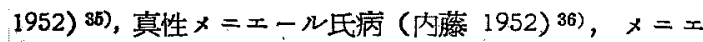
ール1型(渡辺 1954) ${ }^{44)}, x=x ー ル A$ 群（诺 1955） 21) 等之同一のものと考光られる.

上上の如き 臨床像を示す症例を厳密に選び，昭和 31 年より 33 年に至る 3 年間に 観察し得た 30 例（男子 16 例，女子 14 例，年令 17 寸より 54 才まで）につき，検討 を行つた。

また睹量を訴える患者で，上記分類に入らぬるの，即 ち脑量発作は实発的であつても周期的な反復のみられな

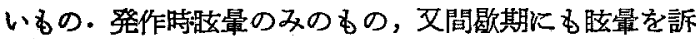
えるるの等, 従来 氏病, atypical Ménière's disease 等と呼ばれていた すの30例についても検討を加えた。

中枢性疾患としては，脳腫瘍，㭙にその局在の明瞭な 症例（手術，あるいは剖見によりその局在部位の確認さ れたもの)が最も望ましいが，しかし希望する部位に限 局した病变がるられる例を臨床例より選ら゙ことは非常に 困難であつた：そこで病変が中枢にあると考えられる症 例として，小脳嗹堭 6 例，小脳橋角腫境 2 例, 前頭頭頂 部腯海 4 例, 前頭側頭部腫瘍 4 例， Parkinsonnismus 2 例, Tabes dorsalis 3 例，Spät Epilepsie 1 例，

Atroph. cerebelleuse tardiv., Basiral Meningitis.

Diabetische Neuropathie. Mangan Vergiftung. 各 1 例, 計 32 例につき検鉂を行つた。

\section{IV. 検查成績並び考按}

\section{1. 自発眼振}

眼位をどの位置にしても一定方向に向う眼振のみられ る場合を方向固定性自発眼振とし，右方凝視と左方凝視 のどちらにも自発眼振の認められるるのを，方向不定性 自発眼振とした. 自発眼振の発莧率を第 2 表に示す.

$x=ェ ー ル$ 氏病 30 例の大部分”，80\% は自発眼振を認 めない.これはメニェール氏病の患者はその発作が終つ た㭙期に受診するため，間歇期に検查することが多いた

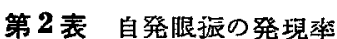

\begin{tabular}{|c|c|c|c|}
\hline & 痛了 & 仮 $\times$ 游 & 门枢性聅患 \\
\hline 方向固定性 & $6(20.0 \%)$ & $2(7.3 \%)$ & $8(26.7 \%)$ \\
\hline 方向不是性 & 0 & $1(3.6 \%)$ & $4(13.3 \%)$ \\
\hline 自発眼振 $(-)$ & $24(80.0 \%)$ & $24(89.1 \%)$ & $16(53.3 \%)$ \\
\hline 垂 㨁 性 & 0 & 0 & $2(6.7 \%)$ \\
\hline & 30 冽 & 27 例 & 30 例 \\
\hline
\end{tabular}

めであろう・なおメンェール氏病では自発眼振があれば すべて方向固定性であることは注意を要する点である う.このことは方向固定性自発腿振は末梢疾患牌有で あるとする従来の見解と一致する・自発眼振の有無，方 向等は検查の時期によつて異るから今後更に例数を増し 検討したいと考えている。

\section{2. 頭位眼振}

Barany (1921)の により記載されて以来, Nylén (1950) ${ }^{37)}$, Lindsay (1945) 31), Dix, Hallpike (1952) 16）等により研究され，頭位眼振は前庭機能検査におけ る基本検查の一つとして認められている.

頭位眼振の 正確な 定義を下すのは容易ではないが， Lindsay, Nylén 虫次のよ5に述べている. 即ち自発 眼振は普通の直立頭位でみられるむので，頭位の变化と は無関係に同じ強さで持続するものであり，頭位眼振は 頭が直立頭位以外の他の位置に変换された陵にみられる るので，頭位によつて眼㧓に変化がみられるものである という.

頭位眼振の観察に当つては Cawthorn (1954) 12) の 方法に淮拠しているが，頭位变換後は直前方を疑視させ て観察を行らのみならず，穴右上下を疑視させ，その眼 位で現れる眼振をも観察し，変化があればこれも記載す ることにしている。

方向固定性頭位眼振とはいかなる頭谈でも必づ一方向 に向う眼振の兒れるものを指す。また一頭位にの眼振 の認められたものも方向固定性とした. 方向不定性と は，各頭位で発来する眼赈の方向が異るむのを指す。

検查成績を第 3 表比示す。

メニエール氏病では自発腿裖を認める例は, 前述の如 く20\%に過ぎないが頭位眼振を認める例は割合に多く 50\%に達している．しかもこの50\%のらち1例を除く 他の全例が方向固定性の頭位眼㖘を示した。これに反し 中枢性疾患では，自発很浱を認めたもの $40 \%$ ，頭位眼 振を認めたるの 47\%で両者の閒に著差がない、またこ 
第 3 表 頭位搌振の発現率

\begin{tabular}{|c|c|c|c|}
\hline & × 㵐 & 仮 $\times$ 嗬 & 枢性疾虫 \\
\hline 方向固定性 & $14(46.6 \%)$ & $\overline{5}(19.2 \%)$ & $4(13.4 \%)$ \\
\hline 方向不定性 & $I(3.4 \%)$ & $5(19.2 \%)$ & $10(33.3 \%)$ \\
\hline 頭位眼振 (-) & $15(50.0 \%)$ & $16: 61.5 \%)$ & $16(53.3 \%)$ \\
\hline & 30 恻 & 26 例 & 30 例 \\
\hline
\end{tabular}

の $47 \%$ の頭位眼振のうち方向不定性の 頭位眼振を呈す るものが33\%の多きに認められるのは， 病の場合と対憗的である.この成績は Nylén, Cawth. orn 等の報告と一致する。

頭位眼振の観察は比較的簡単であるが，臨床的意義は 大きいここのため前庭譏能検查として頭位眼层の祫查は 是非とも行われるべきであろう.

3. 足踏検查

平衡機能検查法として私は Romberg test, 足踏㰸 查, past pointing test の三盾の方法を取上げたが, この三種の䖽查法のうち，Romberg test $と$ past poi nting test では異常所見を呈するものは極めて少かつ た・そこで私は主として足踏検查の成績を検討した。

福田等によれば，正常人では1）足踏終了後も原位 置に正まる－2）前方 $1 \mathrm{~m}$ 以内の移行と左右各 $30^{\circ}$ 以 内の仺䎐並びに移行角を示す.3）原位置より後方に移 行するものはない, という。

福田教授は本法により従来証明し難つた迷路機能の潜 在性不场衡を検出し得るとし，迷路機能の不均衡が骨格 等，特に下肢筋に扣いて迷路性筇緊張の羡異として現れ るためであると解釈している・私は本検查法による偏倚 の方向と, 眼振方向の関係を検討してみた。その成續を 第 4 表に示す.

第4表 足踏検查におりる偏倚

\begin{tabular}{|c|c|c|c|}
\hline & 河 & 仮 × 洋 & 中枢性疾患 \\
\hline 腿振側偏倚 & $2(6.8 \%)$ & $9(34.6 \%)$ & $3(13.0 \%)$ \\
\hline 非腿振測偏倚 & $10(34.8 \%)$ & $1(3.9 \%)$ & 0 \\
\hline 正 & $17(58.4 \%)$ & $16(61.5 \%)$ & $20(87.0 \%)$ \\
\hline & 29 冽 & 26 冽 & 23 例 \\
\hline
\end{tabular}

眼振側偏倚とは，足踏偏倚方向が自発眼振，あるいは 頭位眼振が認められる場合はその眼振方向（方固定性の 場合)，D.P. の認められる場合注，D.P. 万向上一致方 る 多のいら. 非眼振側偏倚とは，これらの眼振方向が
相反するるのを指す・全く偏倚がみられないがあい は正常範囲のものは正常と判定した。

足踏険查で偏倚が誌みられたるのはメ二ェール的病

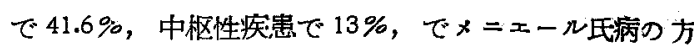
が遥かに多い：その偏倚方向は非眼振側に向5ものが 34.8\%を占めている.このことは末梢迷路刺战沉より眼

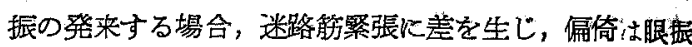
緩徐相に起るといら事実と一致する・これに反して中枢 性疾患で痌倚を認めたるのむ３例に過ぎず，またその全 例とも腿振吅偏倚をみたことは與味深い。

4. 趣転検 查

廻転による眼振険查は Barny 以来臨休挨查法として 広く行われてきたことは周知の通りであるが，前述のよ うに廹転検查は左右迷路を同咕に刺㦸寸るという久点を 有し，また余りに強い延転刺战を繰返すときは，次第に 反応減鹏するとい5 (Dodge 1923 1†), Hood 1954) 18). このことは reseponse de:line (R.D.) 現象として知 られているところである.Hood は家鬼を用い繰返し行 つた迴転刺战さ R.D. 現象を起し，休養期間を作つても 当初の值に戻らないが，温度検查ではか小る現象は起き 孛いと述べている。

私は 30 秒 5 回転の 弱刺战を用い廻忶検查を行つたの であるが，その成績判定に当つて眼振持続時間をとり， 左右廷転後腿层の 持続時間に $20 \%$ 以上の差のあるるの を左右差ありとし，20\%以下のものは左右差なしと判 定した.その成績を第 5 表に示す.

第 5 表 趈输検查による空右応

\begin{tabular}{|c|c|c|c|}
\hline & 洞 & 仮 $\times$ 痱 & 中枢性疾患 \\
\hline 支右表かり & $15(50.0 \% 6)$ & $9(36.0 \%)$ & $14(46.7 \%)$ \\
\hline 左右差なし & $15(50.0 \%)$ & $14(64.0 \%)$ & $16(53.3 \%)$ \\
\hline & 30 测 & 23 洌 & 30 例 \\
\hline
\end{tabular}

この方法で左右差を涊めたのは，メニェール氏定で $50 \%$ ，仮性 でつた。これは後述するように温度検查における左右差 の検出率よりる低率である。

5 . 温度袷查, 冷温交互試留

温度性眼振つ発兒機序については，現在なお不明の点 が少くないが，今日一般記認められている説は，Barany (1906) 6) の内リンパ流動説である ・ 即ち温度变化は側 頭骨を伝わり，水平半規管つ最も側方部汇達し，冷刺战 は内リンパの比重を高め，温刺战はその比重を低め；こ 
机炕よつて起る内リンパの流動が前庭神経終末細胞を刺 戊し，眼振が発莧するといら説である。

Barany の内リンバ流動説を不動にした Steinhausen (1931) +1)の実轲は重要である.即ち彼は Hechte(pike) の半規筸澎大部において，Cupula の動きを観察するこ とに成功し，温度刺战によって Cupula が偏位し，眼 振が発来することを確認した。同じく Maier, Lion (1921) 382 万沜の半規管について観察し，内ッンパの流 動空確認している。

Schmaltz（1925）は外耳道注水つ際の 半規管の温度 変化を測定しここれより内リンパの流動速度を訫算し た. そしてこの計算値と，Fischer.Veits のいう Pulsion Reflex の経過が極めでく一致することを認める と共に，眼振方向の逆転るこの計算式によつて説明して いる. 又甲能 (1954) 29) の外取道注水の 際の側頭骨に

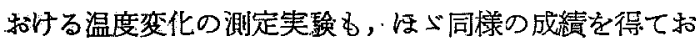
り，半規管の温度変化と，足踏祫查の偏倚との間に密接 な関係があることを指摘している。

以上の実験成績さいずれる Barany 説を支持するる のであるが，廻転と温度刺此で内りンパの流動に差異の あることは当然で，温度刺㦸の場合はゆるやかな持続的 なリンパの流れが起り，廷轱刺㦸つ場合心急速な短特間 のリンパ流動が起るものと考兄られている.

温度性眼振検查に当つてその成績に影響を与兄ると思 恃れる因子は多いが, Arslan (1955) 31 は次の点をあげ ている. 即ち 1) 水温，2）水量，3）注水速度，4) 水の直接当る場所，5）鼓膜と水平半規管の外側壁の間 の骨性 bridge の大きさ pneumatisation，6）血流 の速度.このらち注水量, 注水温度に関しては Jongkees (1949) 25) の詳細な報告がある. 即ち眼振持続传涧 住注水温度と密接な関係があるが, 注水量つ変化には余 り影響を受けない，换云すれば注水温度を一定にすれば 注水量には大した影響は受けないと述べている。

注水量及び注水温度につきこれと同様つ検䛅を行つて いる猪，早川 (1951) 非 あほ心゙同様の成績を得ている. 注水速度に関しては，余りに速かに行うときは外耳道え の圧迫の影響が考慮されねばならないから，私行 $30^{\circ} \mathrm{C}$ ， $20 \mathrm{cc} 10$ 秒間で注水するよらにしている．注水部位は 外耳道後上壁を目標としているが，このために注水に用 いる注射筒 $(20 \mathrm{cc}$ のすの) の先に直徍約 $2 \mathrm{~mm}$, 長さ $25 \mathrm{~cm}$ のゴム管をつけ，その切口を斜めとし，その切口 が外耳道後上壁に向らようにして注水を行っている。

次に骨性 bridge と pneumatisation の問題である
が，これは個体差があり，潜伏代間值直関保するるの であるから，真の潜伏晊間を正確测定するためにはこ の因子をできるだけ除外する必要がある・僣の Z-Test なる検查法はこの目的にかなつた優れた检查法とい兄る が，これについては後述する。

最後火血流の問題であるが，外耳道注水に上る温度变 化の伝尊の際には，周囲の血流により放爇が行われるこ とは当然で，この影響を無視することはできない，しか しこの血流の西子を一定にすることは困難で，この方面 の研究む少いが今後是非とも検討寸べき課題であろう.

温度性眼振㭘查の判定に当つて私仗 $30^{\circ} \mathrm{C}, 20 \mathrm{cc}$ 注水 による眼振持続時間に $20 \%$ 以上の差のあるすのを左右 差ありとし，20\%以下のるのは左右美なしとした。そ の成績を第 6 表に示す。

第 6 表 洫度検查による左右差

\begin{tabular}{|c|c|c|c|}
\hline & $\times \quad$ 荫萑 & 仮 × 荫 & 中枢性笑患 \\
\hline 左右琴市り & $25(86.0 \%)$ & $17(77.2 \%)$ & $20(66.7 \%)$ \\
\hline 左右差なし & $4(14.0 \%)$ & $5(22.8 \%)$ & $10(33.3 \%)$ \\
\hline & 29 测 & 22 冽 & 30 例 \\
\hline
\end{tabular}

次に $30^{\circ} \mathrm{C}, 20 \mathrm{cc}$ と $44^{\circ} \mathrm{C}, 20 \mathrm{cc}$ 交互に注水する冷 温交互試駼を行つて Hallpike 等の提唱せる directional preponderance (D.P.) 仗び canal paresis (C. P.) の有無について検馀した。因みに健康者 20 人 40 耳 の冷温交互試䬸による(フレンッェルの眼鏡を使用し。 直前方視で観察）潜伏時間と眼层持続時間の平均值は第 7 表の通りである。

第 7表 冷溫交互試酸:の正管值 \begin{tabular}{l|l|l|l|l|l}
\hline $30^{\circ} \mathrm{C}$ & $20 \mathrm{c}$ & 平均潜伏時間 & $12^{\prime \prime}$ & 平均腿振持続時間 & $72^{\prime \prime}$ \\
$44^{\circ} \mathrm{C}$ & $20 \mathrm{cc}$ & 平均督伏時間 & $12^{\prime \prime}$ & 本均腿振持続時間 & $56^{\prime \prime}$
\end{tabular}

次に冷温交互試験の成績を第 8 表に示す。

第 8 表 冷盢交互試毁比にる D.P. C.P.

\begin{tabular}{|c|c|c|c|}
\hline & 将 & 便 $x$ 将 & 中枢性知患 \\
\hline D.P. & $14(46.6 \%)$ & $9(40.9 \%)$ & $12(41.4 \%)$ \\
\hline C.P. & $13(43.3 \%)$ & $9(40.9 \% 6)$ & $7(24.1 \%)$ \\
\hline 正 常 & $3(10.0 \%)$ & $4(18.2 \%)$ & $10(34.5 \%)$ \\
\hline & 30 例 & 22 刿 & 29 冽 \\
\hline
\end{tabular}

前庭及応正常と判定されたるのは冷温刺战に上る眼振 持続時間が活よ゚正常で，左右差がないもの．D.P. 陽性 
と判定されたものは冷温刺㦸による眼振持続晊間に差異 があり，乙か子冷水刺㦸の場合之温水刺战の場合，それ ぞれの眼振優位方向が一致するるの（即ち冷水刺战では 右向き眼振が優位で，温水刺㦸でも右向き眼振が僋位の 場合，これを右向 D.P. と判定する)，これに反し一側 耳の冷温两刺战による眼振持続咕間が何れも反対側に比 し:㰯ものを C.P.と判定した.

前庭機查椧查に際し，臨床的に重要なことは眼振左右 羑 (vestibular asymmetry) の有無を確認することで ある.左右迷路機能の著明な unbalance は自発眼振と して現れ，軽度の場合は眼振左右美として現れる(菻本 1955) 34). 従つて軽度の左右迷路の unbalance の存在 を確認する眼振検查法が臨床的には重要である・そこで 同一患者につき迴転検查と温度䄼查に上る成績を比較す ると，第 5 表，第 6 表の如くいずれの場合も温度検査の 方か迴転検査に比し高率に眼振左右养を発見し得ること が解る。

次に D.P.について考学てみたい. D.P. とは迷路を いかなる方法で刺战しても一方向に向う眼振が儤位に出 る壦合を指し，Hallpike 等は冷水及び温水の交互注水 によつて得られた眼振持続時間の閣係から D.P. を判定 し, Kobrak (1952) 28) は冷水刺战之䞟転刺㦸とを組合 は外て，眼振優位方向が一致する場合をZentrale $\mathrm{Ny}$ s a z musbereitschaftsspezifität 即ち” Nystagmusbereitschaft ありとし，不一致の場合沬 Nystagmusbereiischaft なしと判定している. Hallpike は D.P.を Nystagmusbereitschaft と同一視して，その原因を utricle に求め, utricular paresis が D.P.の原因なら んと考えているが, Kobrak は Nystagmusbereitsc. huft は中枢性起源に基くものと考六ている.

さて，D.P.の発原機序については古くから種々の実

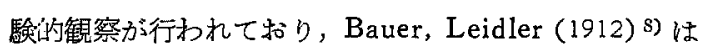
家旡の大脳半球切除後にこのような所見を認めて括り， Hallpike (1942) ${ }^{11)}$ は20例の大脳腫䤃患者につき検 討し10例に D.P.を認妨ている. Langraf (1949) 30) む側頭葉腫瘍に括いて D.P.なる所見を認め, Ander-

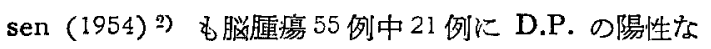
ることを認めている. Kirstein, Preber (1954) 27)は 64 例の脳病変中 27 例に D.P. を認め，その 25 例に脳 波に異常所見を認みている. 森本 (1955) 31) は眼振高 次区射马, 即ち眼振調節回路の unbalance が中枢性 D.P.の原因となるとし，臨床観察より側頭葉と小脳半 琒がこれと密接な関係があることを認め，又動物実験よ
り，眼振調節機構には大鼡よりる小脳が大きな役割を演 ずるものと推察している.川名 (1956) 26) は坂井 (1956) 39）の実験的研究より，側頭葉より小脳半球を介して前 庭核江至る回路及び高次眼振調節回路に unbalance を 生ずると D.P. なる所見を呈するるのであろらと述べ ている.

このように D.P.なる現象は，脳腫瘍等の中枢性疾患 に現れることは事実であるが，末梢性疾患にるしばしば 認められる・末梢性疾患のらちでは D.P.の発現が多い. 更に文正常人に括いても D.P.の 発現をみるとする粉告もある (Jongkees (1948) 23), Peterman (1953) 28), Thomsen (1953) 49)).

メニェール氏病に D.P. の発現のみられることは， Hallpike 等の報告にみられる通り明らかである・私の D.P. に関寸る検查成績は第 8 表の通りで， 氏病で $46.6 \%$ D.P.がみられ，最も発現率が大き w.

次に D.P. の方向と患側との関倸についてみると， 患側の明膫なメニェール氏病について得られた結果は第 9 表の通りで，患側向 $57 \%$ ，健側向 $43 \%$ となり，D.P. の方向に一定の傾向はみられない。

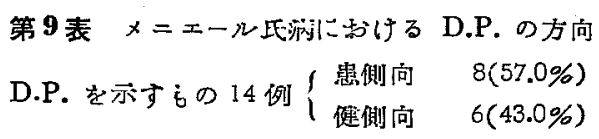

Hallaike 等は末梢性 D.P. の発現は主として utricle の障碍 (utricular paresis) によるものであろうとし ているが，私は後述する Caloric Pattern Test の成 績と考夏合はせ，この説に同意したい。

中枢性 D.P. の方向に関しては Hallpike 等の側嘼 葉腫湯例では，全例患側向であつた事実より，この領域

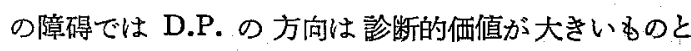
いえる・しかし，その他の部位，特に小脳障碍にあつて は，D.P.の方向はまちまちで，このことは私の家鬼に 物ける脳破壊実験によつてる明らかである。

私の臨床検查成精では, 中枢性疾患の病巣部位とD.P. の方向との間に一定の関係は認められなかつた。

xニエール氏病につき詳紬な前庭機能検查を行つた塔 (1956) 22) は，従来メニエール氏病では患側耳の前庭 能は低下しているすのが多いとされているが，発作直腾 では械能六谁例が多数存在することを指摘し，発作を嬠 返した古いメニェール氏病では機能低下を認める例が多 いと述べている。 


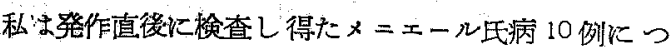
き，これが D.P. を示すか，C.P.を示すかをしらべて みた・即ち冷温交互試験で D.P. を示する 7 例, C.P. を示するの3例であつた．何回す発作を繰返した例で， 間歇期に測定した 8 例についてみると，D.P. を示すも の1例，C.P. を示するの6例，不明 1 例となり，C.P. 孝示するのが多い(第10表).

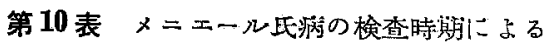
D.P., C.P. の制定

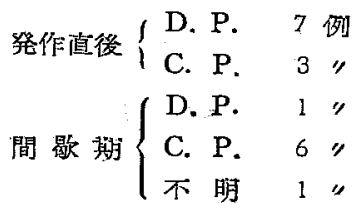

以上少数例ではあるが，発作直後では D.P. を示する のが多く，閒歇期には C.P. 例が多いことは上迹の猪の 説を裏最きしているものと云えよう。これを要するにメ ニェール氏病で，発作佶注自発眼振を認め，発作直後， 自発眼振の消失した時期には方向固定性の頭位眼振を認 め，この咕期には D.P. を示すものと考觉られる.そし てこのような発作を繰返すうちに，患側迷路の機能低 下，即ち C.P. 老呈するるのであるら.勿論一回の発作 ですぐ機能低下，又は脱落を起し，C.P. を呈するむ のがあることる当然である。

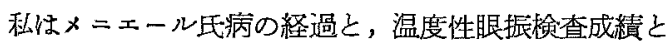
の関係から， ているが，これについては今後症例を増し別の機会に発 表したいと侾ている.

以上述べた温度性眼振検榃によつて，D.P. 又は C.P. の有無及び D.P.の方向之患側等について検討を行つた が，この成績から中枢性か末梢性かの判定を下すことは 困難であつた－従つて温度性眼振検查によつて病栄の局 在診断を行ら場合，更に進んだ検查法が必要となつてく 3 .

\section{Z-Test}

Z-Test は㒂の侾案した温度性眼振検查法で, 真の意 味の潜伏時間を測定する方法である・乳様突起削開術を 行つた人間について，骨性迷路の温度変化が外耳道注水 によつていかに経過するかを追及した甲能 (1954) 29) の 実験代基づいて，猪法潜伏時間を第 3 図の如く分析し た.

即ちこの図で明らかなように，潜伏時間は $a+b$ で表 れされる・この $\mathrm{a}+\mathrm{b}$ が従来いわれている潜伏㭙間であ

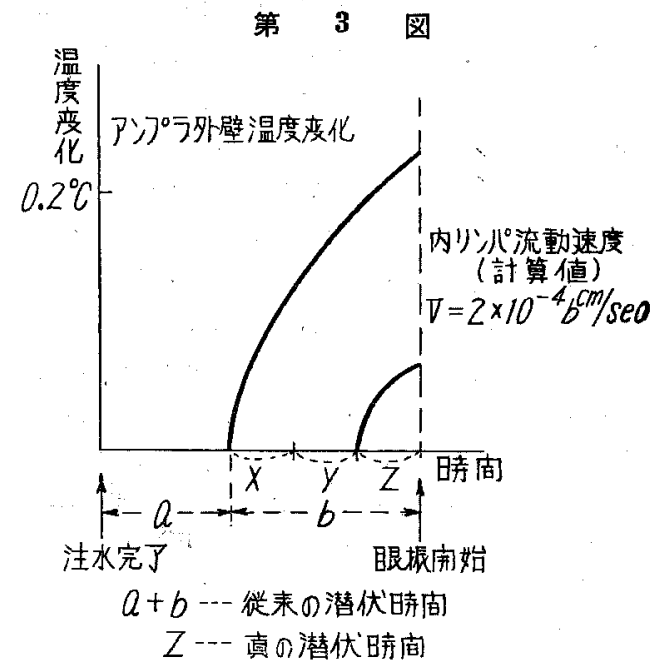

る・a は外耳道注水が終つてから水平半規管 アンプラ (骨性迷路)に温度变化が現れるまでの膰であり，b はアンブラに温度変化が現れてから実際に眼振が始まる までの洁間である・なる汪ど、は側頭骨の解剖学的慛 造により左右さ机る值であるが，b付前庭迷路の與奮性 を示可值と考兄られる。しかしてb更に詳しく方析 すれ梳， $\mathrm{b}=\mathrm{x}+\mathrm{y}+\mathrm{z}$ となる・ $\mathrm{x}$ は水平半规管アンプ (骨性迷路) の温度変化が外リンパ膑を経て膜様迷䟲に

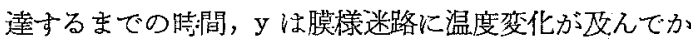
ら内リンパの流動が始まるまでの猎間，z は内リンバの 流動が始まつてから眼振が起るまでの搭間を意味する。 内リンパの流動が始まつても直らに眼振が起るわけでは なく，内リンパの流速が一定度以上に達して始めて前宿

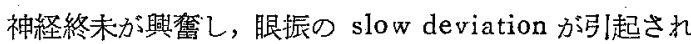
るものと考えられる。この $\mathrm{z} こ そ$ 真の潜伏時間とい壳

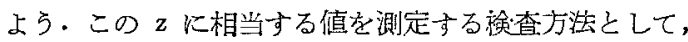
猪は次の如き方法を提案した。

即ち被験者の頭位をおよそ前屈 $30^{\circ}$ の頭位 (indifferent position) に固定する，次に $30^{\circ} \mathrm{C}$ の冷水 $20 \mathrm{cc}$ 老 10 秒間で外耳道後上壁に注入する。この頭位では水平 半規管が水平になつているから外耳道注水によつて迷路 に温度変化が生じても内りンパ流動は起らず，従つて眼 振和起きないわけである・外耳道注水開始から1 万後に 被験者の頭位を前屈位より直立頭位にする。この直立頙 位にしてから一定の潜伏㬐間をおいて眼振が始まり，一 定時間持続するこの潜伏時間と眼振持続時間を测定する のであるが，眼振の観察に当つてはフレンッェルの眠鏡 を使用している．外耳道注水開始加ら1分後に頭位变换 
を行ら理由は，前述の迷路の温度変化に関する実験によ つて内ッンパの流速が注水後 60 秒で淰ら゙最大の值に達 することが解ったからであり，また 60 秒間 indifferent positionにして括くことにより注水に基ぷく外耳道反 射等の影響を防ざ得るのではないかと考吝たからであ る・頭位変換を余りに急速に行うと潜伏猎間が短縮す る.しかし頭位変換をゆつくり行えば眼振の発来なしに 最大刺㦸位にすることができる(Veits, Kosel 1930) 43).このため私恃頭位変換を2秒間で行っている.要す るにZ-Test は迷路に充方温度变化を起して括いてか ら頭位变換を行い，内ッンパの流動を引起し，この瞬間 から眼振発来迄の封間を測定するとともに，眼振持続㭙 間をす計湘する方法である。

温度性眼振検㚗に拈ける潜伏陵間の重要性を強調して いるものに Alexander, \& Brunner (1922) 1), Atkinson (1939) ${ }^{4)}$, Wodak (1952)45), Demetriades (1952) 13) 等があるが，わが国の多くの学者や，Hall-

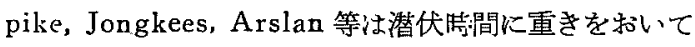
いない.

A rslan (1955) 3) は潜伏時間の診断的喼義を否定し， 潜伏時間の長さは末梢前庭装置の变化によるものではな く,むしろ解剖学的因子, 即ら Schmaltz p Dohlmannによつて証明された水平半規管の外側壁と鼓膜と の間の骨性 bridge の大きさと, pneumatisation の変 化及び血流の速度等によつて変化するものであろうと考 えている. Wodak (1952) 45) は同一人で潜伏陆間が非 常侸かかつたものが，数時間後に正常の潜伏時間に復 した症例の経験から，このよらな事実は骨性 bridgeの 解剖学的変化によるものと考觉難いとし，潜伏時間は末 梢前庭装置そのもの〉状態を示すものであると強調して いる.

正常人 25 例 50 耳について行つた Z-Test の成績は 第11表に示す通りである.

この成績より，潜伏時間は6〜9 秒，眼振持続時間は 30〜50 秒を正常範围と考えたい。

さて Z は前述の通り内リンパ流動が始まつてから眼 振が起るまでの封間を意味するから末梢迷路の與奮性を 示すばかりでなく，迷路性眼振反射弓，更に眼振高位中 枢の與奮状態をも示していることになる・眼振持続畤間 もまた末梢迷路のみならず，眼振反射弓，眼振高位中枢 の状態によつて左右されることは明らかであるから、こ の $Z$ と眼振持続時間の組合せから中枢性病変か，末梢 性病変から判定がある程度可能である.そこで猪は第 4
第 II表 Z-Test の正常值
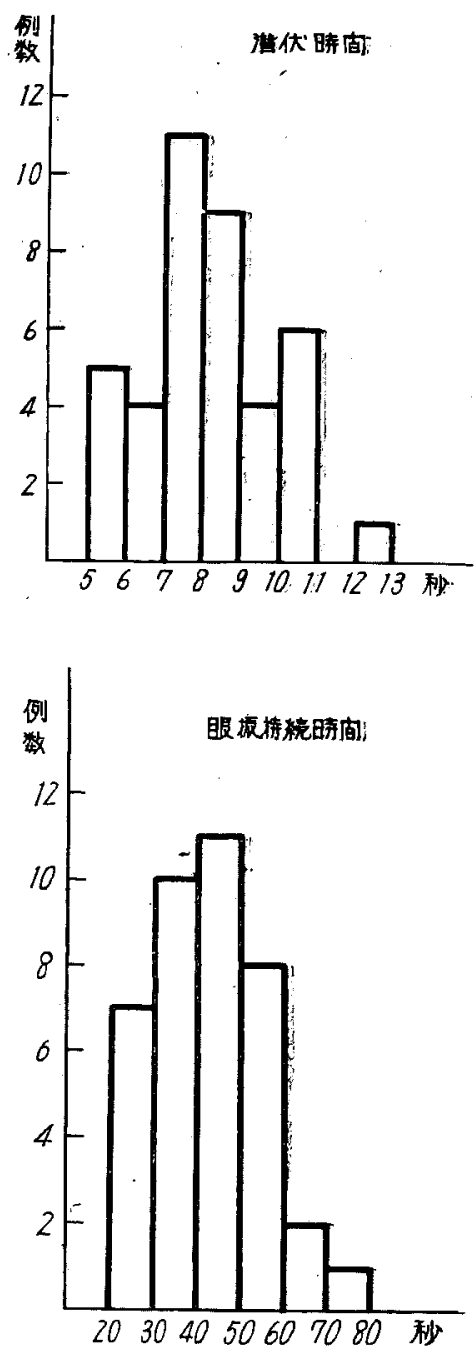

第4图 Z-Test による中枢か未梢かの制定

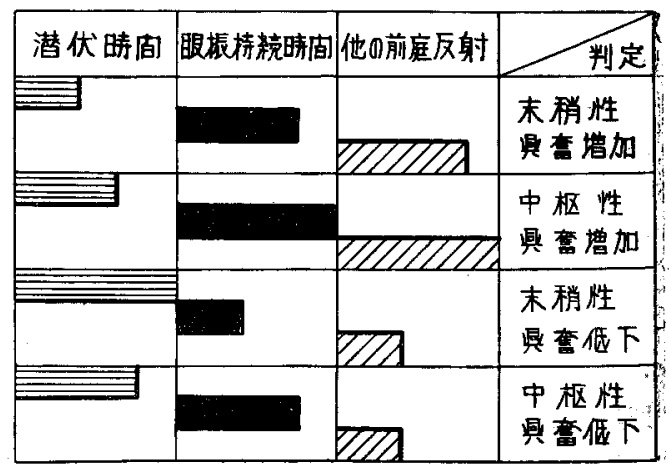


因の如き鑑別表を作裂した。

末梢性與鹪堌加と仿，Z に相当する 潜伏時間が短か く，眼振持続㽦;間は長く，他の前庭反店当強い中枢性

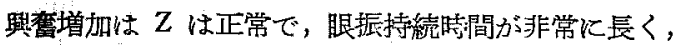
訛の前庭反応子非常に強い：末稍性罢奮低下は Z が非 常に長く，眼振持続禁間が短かく，他の前庭反応が非常 火弱い. 中枢性興奮低下は Z が正常かや長く，眼振々 の他の前庭反店が弱く短い。

以上の判定による成續は第 12 表の通りである。

第 12 表 Z-Test による成綪

\begin{tabular}{|c|c|c|c|}
\hline & 瘕 & 仗 $\times$ 病 & 中枢性矫露 \\
\hline 末梢性興窝筧加 & $4(13.3 \%)$ & $3(11.5 \%)$ & $5(15.606)$ \\
\hline 低下 & $14(46.6 \%)$ & $8(30.7 \%)$ & $1(3.1 \%)$ \\
\hline 中枢性興鹤堦加 & $1(3.4 \%)$ & $8(11.5 \%)$ & $7(21.9 \%)$ \\
\hline 低下 & $2(6.7 \%)$ & $3(11.5 \%)$ & $7(21.9 \%)$ \\
\hline 正 & $7(23.3 \%)$ & $7(26.9 \%)$ & $7(21.9 \%)$ \\
\hline 不 & $2(6.7 \%)$ & $2(7.7 \%)$ & $5(15.6 \%)$ \\
\hline & 30 冽 & 26 例 & 32 冽 \\
\hline
\end{tabular}

Wodak (195天) は從来の検查方法で 得られた潜伏特: 間と眼振持続佶間の関係か 5 peripheral hyperexcitability, central hyperexcitability, peripheral hypoexcitability. central hypoexcitability の 4 つに方, 類 $\iota$ ，眼振持続咕間の変化は中枢の checking mechanism によるものと述べているが，このような往来の咬查方法 によつて得られた潜伏咕間と腿振持続時問の間係から中 枢性が末梢性かの判定を行らのは無理であるう。

Z-Testを追試した川名（1956）20) はメ＝ェール氏病 の如く内耳障碍の場合は，Z-Testによる潜伏睛間住一 律に短維し，持続腊間は前庭反心充進時には延長し，前

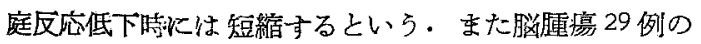
成續より，中枢性障碍の場合の Z-Testによる潜伏時: 間は，前庭眼振反射弓に䦎連ある部位の障碍では正常で あり，前庭眼振反射弓に関䢙を有せず，髄液纴九進，脳 血流障碍，脳圧迫等の二次的影響が内耳に波及し得る場 合には末梢性障碍の形で現れるという。

私が行つた 成䒈は第 12 表に示した通りであるが，Z-Testによる 潜伏時間に短繀または延長の見られたるの，即ち末梢性 興鹪堌加及び末枌性與奮低下を一括して末梢型とし, 及 中枢性與鹪増加及び中枢性與奮低下を一括して中枢型と

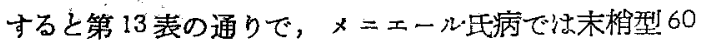

第 13 表 Z-Testに上る成績

\begin{tabular}{|c|c|c|c|}
\hline & 漭 & × 㴟 & 五枢性疾患: \\
\hline 枺 梢 型 & $18(60.0 \%)$ & $11(42.2 \%)$ & $6(18.7 \%)$ \\
\hline 中 枢 型 & $3(10.0 \%)$ & $6(23.0 \%)$ & $14(43.8 \%)$ \\
\hline
\end{tabular}

$\%$ ，中枢型 10\%，中枢性疾患では中枢型 43.8\%，杢梢 型 $18.7 \%$ を示した。

以上の成繂より Z-Test による中枢性病変か未梢性 病変かの判定注かなり信頼度が高いといえる・

7. Caloric Pattern Test

Z-Test で眼振の発来をみない埸台注本洁による判定 は不可能となる・徉つて眼振の発来がみられる变で頭位 を更に媵屈せしめる必要が生ずる。このよらに頭位る次 第に後屈せしめることによつて，迷路に与える刺战を階 段的に強め，各頭位に牤ける眼振持続時間を測定し， これを一つの pattern として観察しようとするのが Caloric Pattern Test である. 即ち同一性望の刺战み 何点かの刺战として与え，その成續を二つの pattérn として表わさんとする試みである。

Caloric Pattern Test の実際蜎項に哥いて逨べた のでこっでは省略する。

健康人 25 例 50 耳について行つた Caloric Pattern Test の正常值を第 14 表に示す.

第14表 Caloric pattern Testに上る正常僨

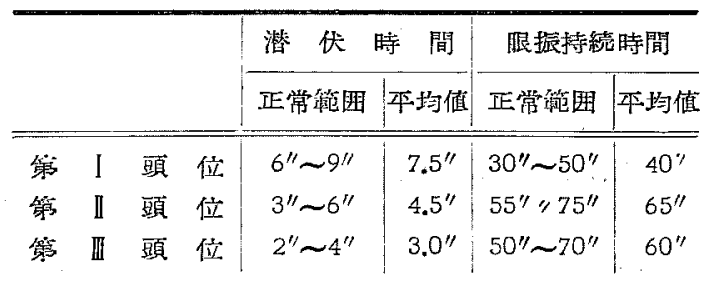

$30^{\circ}$ の頭位を第 I頭位， $60^{\circ}$ の頭位を第II頭位， $90^{\circ}$ の頭位を第頭位亡寸ると，潜仗制間は第 I，第 II，第 哑位の順に短かくなつているが，眼振持綕時間は第 II，第III，第 I 頭位の順になつている.㻎論的には第 II 頭位蚛水平半規管が垂直になつている位置であるから内 リンパの流速が最も速いものと考党られ，眼振持続時;間 も第前頭位が最も長くなることが予想されるが，笑測に

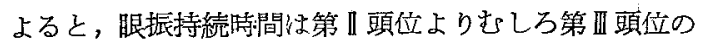
方が短かくなつている・この点にいいて少しく考察を加 えてみたい.

従来より眼振発現機構に関して中枢抑制的に働くも 
のと考えられている．即ら前庭核に対する眼振高位中枢 たる小脳及び大脸注抑制的に㗢き，眼振の発来を抑制す るるのと考えられている・このことは中枢破壊実験によ り眼振抑制作用が消失することからす明らかである。

Caloric Pattern Test の第四頭位に批るる眼振持続

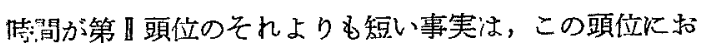
ける刺戟が強いために，眼振の抑制が強く現れたるのと 解せられる・このことは私の家鬼に和ける実験で明らか にすることができた・即ち家東について人間におけると ほメ゙同様の注水を行い，この際眼振持続時間が大脳及び 小脳の破堹によつていかに変化するが追及したとこ ろ，第西頭位における眼振持続間の短縮は明らかに中 枢抑制作用によるものであることが号つた：この実験成 績については追って発表の予定である。

この事実を基礎として，各種疾患における検查成績に いて考えてみよう。

若しも中枢に病変があり，中枢の前庭系に対する抑制 作用が失䏡れるとすれば，その結果眼振発来は容易とな り，眼振持続咕間俚延長し，特に第回頭位に淤ける眼振 持続時間が著明に延長することが想像される・又中枢の 病変によつては逆啝制作用が失はれず，かえつて強化

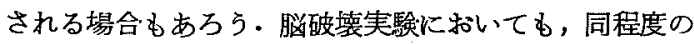
变性像て眼振所見の上からは抑制的に作用することも， あるいは又刺㦸的に作用することもあり得ることが癹め

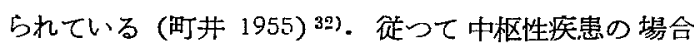
は常に抑制作用が失はれる訳ではなく，かえつて抑制が 強化される場合ああり得るはずである・この場合 patt・ ern としては第价頭位の眼振持続時間の短縮が 当然考 えられる。

次に末梢性疾患之考觉るべきメニエール氏病の patt. ern の特徽について述べる・患側耳注水の場合，第 1 ，第 四頭位では眼振が惹起されないかあるいは極く僅かに認 められるだけであるが，第四頭位では明らかに眼振が発 来し，しかもその眼振持続咕間が健側の第四頭位に括け る值とほぼ等しい值を示す場合がしばしばみられる。こ のような所見は聴器にみられる recruitment phenom. enon と同様な現象と考えてよいのではなかららか.か かる現象は私の今回の観察ではメンエール氏病に多く認 められ，中枢性疾患では認められなかつた。

このような前庭器における recruitment phenomenon (vestibular recruitment phenomenon) について Azzi, Giordano, Spelta (1953) $)^{5)}$ は次の如き論交を 発表している・即ちVeits 法を用いて患側耳注水をく
り返し何回も行うことによつて最初の注水では見られな かつた眼振が，何回目かの注水によつて発来し，しかす そ机が健側耳の最初の注水の值とほ心゙等しい場合がある ことを発見しっこれを vestibular recruitment phen omenon と考光，からる現象は中枢性疾患には認めら れなかつたといつている. しかしてこの recruitment phenomenon の発現機構については聴覚におけるそれ と対比し, 蝸牛の内毛細胞と cupula の相似性を力説 し，これを純生理学的に解釈している.

私の行つた方法は左右耳に同一種類の刺战を与え; 頭 位変換によつて刺战の強さを次第に変化させる方法であ り，健側と患側の迷路にそれそれ同じ強さの刺戟を与兄 て検查し, vestibular recruitment phenomenon 見出す方法であり，聴覚に洛ける Fowler の Biaural Loudness Balance Test に相似の方泆といえる.

Azzi 等の方法法健側の初回注水時:の眼振持続時間と， 患側に何回かの注水を行つた場合に得られた眼振持綕時 間が等しくなつた㭙に recruitment ありとしているが， この点左右耳を比較するという意味では難点があろう。

以上の事実を基碟として私仙各理将患について得られ た patternを 4 つの基本型に分類した（第 5 図）。

\section{第5図 Caloric Pattern Testによる基本型}
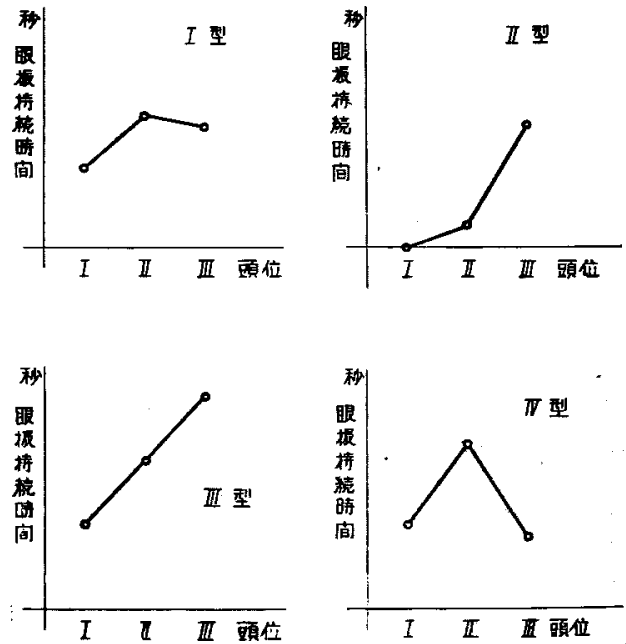

第 I 型は既に述べた通り，正常人にみられる pattern で，第西型は所謂 vestibular recruitment を示す

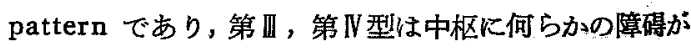
あると考えられる場合の pattern である。

Caloric Pattern Test の成績を第15 表に示す。 
第 15 表 Caloric Pattern Test の成續

\begin{tabular}{|c|c|c|c|c|}
\hline & & 润 & 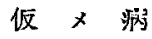 & 中枢性怡患 \\
\hline I & 型 & $14(46.6 \%)$ & $10(38.4 \%)$ & $6(18.7 \%)$ \\
\hline$\llbracket$ & 型 & $12(40.0 \%)$ & $5(19.2 \%)$ & 0 \\
\hline $\mathbb{I I}$ & 型 & $2(6.7 \%)$ & $4(15.4 \%)$ & $14(44.8 ; 6)$ \\
\hline IV & 型 & 0 & $6(23.1 \%)$ & $8(25.0 \%)$ \\
\hline 不 & 明 & $2(6.7 \%)$ & $1(3.8 \%)$ & $4(12.5 \%)$ \\
\hline & & 30 & 26 & 32 \\
\hline
\end{tabular}

さてメニエール氏病 30 例の 成績についてみると，第 I 型を示すもの 14 例 (46.6\%)，第 II 型を示すもの 12 例 (40\%) で， メニエール氏病の大部分 $86.6 \%$ が 皕 I 型を示したことになる・換云すればメニェール氏病の大 部分が正常人と同じ pattern をとるか，あるいは ves. tibular recruitment 陽性型の pattern をとることに なる。

次にメニエール氏病で I 型をとるものと，【型をとる もの゙との間に内容的にどのような姜異があるかを検討し てみた (第16表).

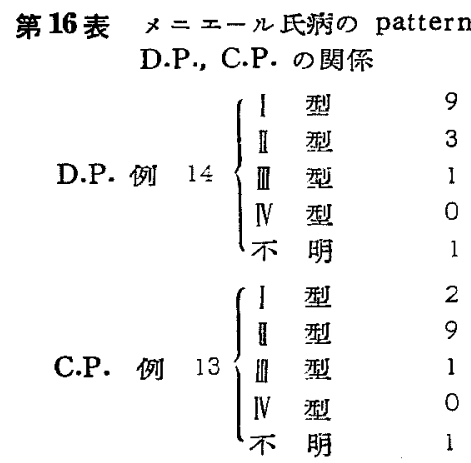

$x=x ー ル$ 氏病 30 例の5ち D.P. 隄性が 14 例（46.6 \%)に諗められたことは前述したが，その中ではI型を とるものが9例で最む多い.C.P. 13例についてみると 】型をとるものが9例で最も多い，即ら D.P. 例では 健側耳と患側耳との間に明らかに差がある 訳であるが pattern としては同じであり，C.P. 例では患側耳と健 側耳の間に明らかな pattern の相異がみられる・Azzi の説の如く cupula に何らかの障碍がある 时に recruitment phenomenon が現れるものとすれば，【型が C.P. 例に多く，D.P. 例に少いという事実は Hallpike 等が D.P. の原因を utricle に，又一側迷路の機能低 下の原因を所謂 canal paresis に拈いている説を稟書
きするものであろう・

即台 cupula k何らかの病変が起つた場合恃冾温交 互試験では C.P.を示し, Caloric Pattern Test では recruitment phenomenon を呈するものと考えられ る.これに反し cupula には变化がなく utricle に何 らかの病変が起つた㘯合（utricular paresis）は D.P. を示するのであろう。

次に中枢性病患32 例についての Caloric Pattern Test の成績を検討する (第 15 表).

中枢に病変がある場合性前述の如く第吕頭位の眼垃持 繶時間に変化がみられることが考えられる. 即ら第正頭 位の眼振持続時間の延長をきたするの（第 III 型），と知 制をきたすもの（第N型）とがあることが考えられる。

私の権察例では开型を示するの 14 例 $(44.8 \%) ，$ IV 型 を示すもの 8 例 (25\%)，I型を示寸もの6例 (18.7\%) で，型を示すものは全くみられなからた。

即ら中枢性突患ではその $70 \%$ が II 型及び W 型を示す が，私の今回の観察では病巣部位と pattern との閣係 を明らかにすることは困難であつた・しかしメニエール 氏病にみられる第11 型が，これら中枢性疾患では全くみ られなからたことは重要であろう。

以上各種前庭機能検查方洼につき, 病紧の局在㟝断上 の価值を比較検討してきたが，病巣の局在診断を行らに 当つては各種検查法によつて得られた成績を綜合判断す ることが必要なことはいらまでもないしかし従来の前 庭機能检查法では病巣の局在診断は殆九ど不可能に近か つた・この意味で Z-Test, あるいは Caloric Pattern Test は目的に一步近づいた模査法といえる・しかしな おわれわれの理想をするところとは程遠い，今後更に祫 㑏を加兄，病巣の局在診断を目的とした前庭譏能検查法 の確立に努力したい。

\section{V. 結 論}

末梢性疾患 30 例，中枢性疾患 32 例につき，自発眼 振，頭位眼振㭘查，足踏㭘查，廻轱検查，温度検查（冷 温艾互試験，Z-Test, Caloric Pattern Test) の成績 を檢討し，次の如き結論を得た。

1) 自発眼振：各疾患之も自発眼振を呈する症例抄少 く診断的価值は少い。

2) 頭位眼振： x=エール氐病では50\%に諗められ， 診断的価值が大きいし娭查法も簡単であるから，臨床検 查として是非行われるべきであらう。

3）足踏検查： められるが，中枢性疾患では偏倚を呈する場合は少い。 
乙かし末梢迷路障碍では非眼振側に偏倚寸る場合が多い から，他の眼振柃查成續と棕合判定すると䛦断上かなり 参考となる。

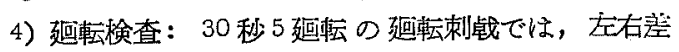
の検出率は温度积亘のそれに比べ低率で, 病紧の展在沴 断上の価值は少い。

5) 冷温交互試哭：D.P. 及び C.P.の有無, D.P.の 方向等から末梢性か中枢性かの判定乃至は患側の判定を 行らことは困難である。

6) Z-Test：潜伏㭙間と眼振持続咕間との関係から 末梢性か中枢性かを糮別する方法であるが，本法による 病单の局在䛦断上の価值放かり大きい:

7) Caloric Pattern Test: 本法つ】型は末梢性疾 忽に特有であり，所謂 vestibular recruitment phen-

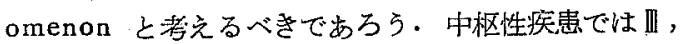
N 型を示すものが多いがこれは中枢の抑制機構の失調 によるるのであろう.

メニエール氏病では I， II琵を示すものが多いが，I 羿を示す ぬのに D.P. 例が多く， I 型を示するのに C.P.例が多い.このことは C.P.例では cupula に， D.P. 例では utricle に何等かの病变があることを意味 するものと推諭した。

\section{主 要 文 献}

1) Alexander, G. Brunner, H.: Uber Labyrinthä. re Ubererregbarkeit. Ztschr. Hals Nasen u. Ohr . er. $3: 243,1922 . \quad$ 2) Andersen, H.C.: Directional Preponderance in some intracranial Disorders. A :ta Otolaryng. 44: 568, $1954 . \quad$ 3) Arslan, M.: On the renewing of the methodology for the sti. mulation of the vestibular apparatus. Acta Otol. aryng. Suppl. 122, $1955 . \quad$ 4) Atkinson, M.: A simple quantitative method of testing vestibular function: Arch. Otolaryng. 30: 916, 1939. 5) Azzi, A., Giordano, R. \& Spelta, O.: "Does a vestibular recruitment exist?" Acto Oiolaryn, 18: 352, 1953. 6) Barany, R.: Untersuchungen über den von Vestibularapparat des Ohres refekorisch ausgelisten rhythmischen Nystagmus und seine Begleiterscheinungen. Monatsch. f. Ohrenh. 40: 193, 1906. 7) Barany, R.: Diag. von Kranl:heitsersch. im Ber. d. Otolithenapp. Acta Otolaryng. 2 : 434, 1921. 8) Bauer, J: \& Leidler, S: Einfluss d Ausschaltung Verschiedener Hirnalis- chnitt auf die Vestibulären Augenreflexe, Arch. Neurol. 19: 155, 1912. 9) Borries, G.V.T.: Expe. rimental studies on the rotatory and the caloric test in pigeons. Acta Otolaryng. $2: 398,1920$. 10) Borries, G.V.T.: Theorie des Kalorischen Nystagmus. Arch. f. Ohren Nasen u. Kehlkopf. 113: 117, 1925. 11) Cawthorne, T.E., Fitzgerald, G. \& Hallpike, C.S.: Studies in human vestibular function: 1) Observations on the directional prepo. nderance (Nystagmusbereitschaft) of caloric nystagmus resulting from cerebral le:ion. Brain. 65: 115,1952 . 2) Observation on the directional pr. eponderance of caloric nystagmus (Nystagmusbereitschaft) resulting from unilateral labyrinthectomy. Brain. 65: 138, 1942. 3) Observations on the clinical features of "Ménière"s disease: with e-pecial reference to the results of the caloric test. Brain. 65. 161, 1941. 12) Gawthorne, T.E.: Positional nystagmus. Annals of Otol. Rhinol. Laryngol. $63: 2,1954 . \quad$ 13) Demetriades, T.H.: The caloric labyrinthine test as $I$ have used it for thirty years. J. Otolaryng. 66: 193, 1952. 14) Dodge, $R$.: Habituation to rotation. J. Comp. Psych. 6: 1, 1923. 15) Dix, M.R. \& Hallpike, C.S.: The pathology, symptomatology and diagnosis of certain common disorderes of the vesti. bular system. Annals of Oto. Rhino. Laryng. 61: 987, 1952. 16) van Egmond, A.A.J., Groen, J.J. \& Jongkees, L.B.W.: The function' of the vestibular organ. Pract. Oto. Rhino. Laryngologica. Suppl. 14，2，1952.17）福田精：身体均衔袎能検查法，足 踏湌查（福田）に就て，耳學臨，38:4, 炤 18. Hood, J.D. \& Pfaltz, C.R.: Observation upon the effects of repeated stimulation upon rotational and caloric nystagmus. J. Physiology. 124; 130, 1954. 19) 猪初男，早川富之助：迷路機能梌查法と乙

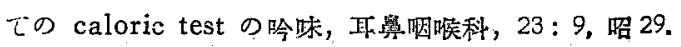
20）猪初男：caloric testにおりる潜伏時間の意我，

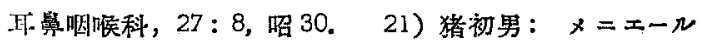

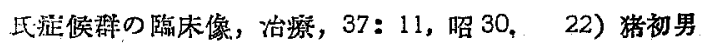
优： $28: 5$, 炤 31, 23) Jongkzes, L.B.W.: Value of the caloric test of the laburinth. Arch. Otolaryngol. 
48: 402, 1948. 24) Jongkees, L.B.W.: Origin of the caloric reaction of the labyrinth. Arch. Oto. 1aryngol. $48: 645,1948$. 25) Jongkees, L.B.W.: Which is the preferable method of performing the caloric test? Arch. Otolaryngol. $49: 594,1949$.

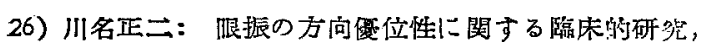
迫信医学, 8: 11, 炤 31. 27) Kirsstein, L.\& Preber, L.: Directional preponderance of caloric nystagrnus in patients with organic brain disease. Acta Otolaryngol. $44: 265,1954$. 28) Kobrak, F.: $Z$ wei Vereinfachungen in der Vestibularisdiagnose. Acta Otolaryng. $42: 96,1952.29$ ) 甲能幸一：溫

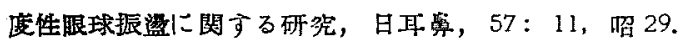

30) Langraf, $F_{.}$: “Dysréflexie vestibulo-oculaire. croisée" “Nystagmusbereitschaft" "Directional Preponderancc" une tentative de synthése. Acta Otolaryng. $37: 85,1649 . \quad 31)$ Lindsay, J.R.: The significance of a positional nystagmus in otone rological diagnosis. Laryngoscope. 55: 527. 1955.

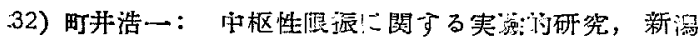
医学雑誌, 69: 10, 昭 30. 33) Maier, M. \& Lion,

H. Experimenteller Nachweis der Endolymphbewegung im Bogengangsapparat des Ohrlabyri. nthes bei adäquater und Kalorischer Reizung. Pflügers Arch. f. ges. Phusiol. $187: 47,1921$. 34)

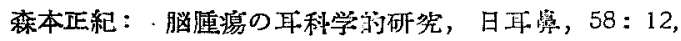
炤 30. 35) Mygind, S.H.: The function and the disease of the labyrinth: lectures on aural medicine. Acta Otolaryng. $41: 235,1952.36)$ 丙藤

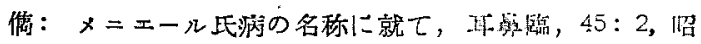
27. 37) Nylén; C.O.: Positional nystagmus a review and future prospects. J. Laryngol. 64: 295, 1950. 38) Peterman, H.: Uber das Vorkommen von Nystagmusbereitschaft beim Normalea. Pract. O10. Rhino. Laryngologica. 15:28, 1953. 39) 渡

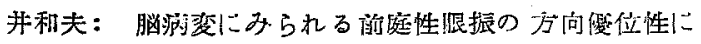

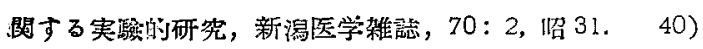
Schmaltz, G.: The physical Phenomena occurring in the semicircular canals during rotatory and thermic stimulation. Proc. Royal. Soc. Med. 25, 1932. 41) Steinhausen, W.: Uber den experimentellen nachweiss der ablenkung der Cupula terminalis in der intakten Bogengangsampulle des Labyrinths bei der thermischen und adaequaten rotatorischen Reizung. Zschrift. f. Hals Nasen u. Ohrenheilk. 29: 211, 1931. Steinhausen W.: Uber den Nachweis der Bewegung der Cupula in der intakten Bogengangsampulle des Laburinths bei der natürlichen rotatorischen und Calorischen Reizung. Pfüger Archiv f. Physiologie. 228: 32?, 1931. Sleinhausen, W.: Uber die Beobachtung des Cupula in den Bogengangsampullen des Lab. yrinths des lebenden Hechts. Pflüger Archiv. 1. Physiologie. 232 : 500, 1933. 42) Thomsen, K.A.: Tae caloric test A.M. Hallpike et al in a normal meterial with special referenze to directional $\mathrm{p}_{\mathrm{i}}$ eponderance in normal subjects. Acta Otolaryngol. Suppl. 109: 15, 1953. 43) Veits, C. \& Kosel, R.: Beiträge zur Lehre vom Kalorischen Nystagmus. Mschr. Chrenheilk. 64：521, 1930. 44) 溲赲预:

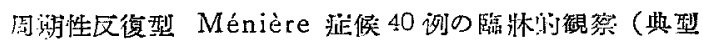

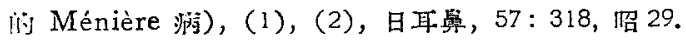
45) Wodak, E.: Diaguostic value of the latency period after caloric stimulation of vestibular apparatus. Arch. Otolaryng. 55: 381, 1952. 46) Wodak, E.: Aural vertigo. Annals of Otolaryng. $62: 130,1953$.

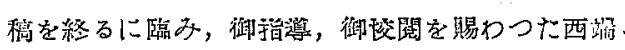

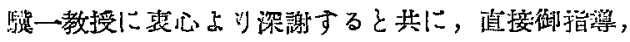
湖鞭灆下さつた狫初男医長に心がら感謝玫します。

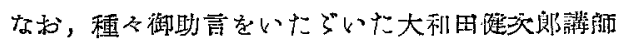
に謝意を哜します。

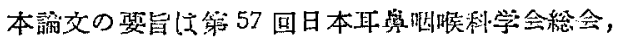

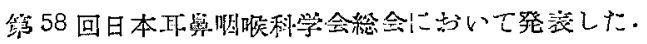

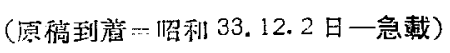

